\title{
Editorial dos 10 anos da Revista
}

\author{
Editorial in honor of the 10 years our journal
}

\author{
Jair Escobar
}

Quando o Dr. Paulo Oscar Teitelbaum me formulou o convite para elaborar o editorial dos 10 anos da Revista, senti-me lisonjeado e surpreso pela velocidade da passagem do tempo. Não imaginava que já tivesse passado tanto tempo assim. Àquela época, o Dr. Luis Carlos Mabilde teve a gentileza de convidar-me para editor da Revista, deixando-me honrado e grato pelo convite. Tamanha responsabilidade passei a dividir com meus colegas do Conselho Editorial, Drs. Rugero Levy, Hamilton Fontoura, Carmen Keidan, Lais Knijnik, Marilia Ghelen, Flávio Pechansky, Gilberto Brofman e Rosane Posimczyk. O Dr. Rugero ficou pouco tempo conosco, pois logo foi convidado a participar como diretor financeiro da Associação de Psiquiatria do Rio Grande do Sul. Também passamos a contar com a capacidade e experiência dos colegas do Conselho Consultivo, Drs. Aldo Duarte, Antônio Carlos Pires, Cláudio Eizirik, Cláudio Osório, Flávio Rotta Correa, Maria Lucrécia Zavaschi, Marlene Silveira Araújo, Raul Hartke, Rogério Aguiar, Sérgio Machado, Sérgio de Paula Ramos e Sidnei Schestatski e a valiosa colaboração de nossa secretária Silvia Bennemann.

Na nossa gestão, fizemos a primeira alteração gráfica da Revista. Foi modificada no tamanho, na diagramação e na apresentação visual do texto, tornando-se mais atual, visando facilitar o manejo e a leitura. Também fizemos alterações no corpo da Revista: o sumário, além de localizado na página de rosto, ocorre, também, na quarta capa; os resumos, unitermos e abstracts passaram para os finais dos artigos, após as referências bibliográficas, reduzindo o volume inicial de informações fragmentárias, proporcionando com isso maior destaque ao título do trabalho e aos nomes dos autores. Além disso, a melhoria do padrão gráfico, além dos caracteres e entrelinhas mais amplos, tornou o texto mais claro e legível. Tentamos inovar nos conteúdos dos trabalhos, e lançamos a ideia "do fórum de debates", onde foi publicado o artigo capaz de suscitar discussão ou controvérsia sobre determinado tema, o qual foi comentado de forma crítica por outros dois colegas. Na seção Notícias, esperávamos que circulasse correspondência dos colegas emitindo opiniões, críticas e sugestões que tornassem a Revista mais dinâmica e participativa no nosso meio.

Ao longo dos anos, a Revista de Psiquiatria do Rio Grande do Sul tem sofrido várias modificações. Isso é decorrente da criatividade e da participação dos seus conselhos editoriais, mas ao mesmo tempo a Revista mantém as bases da psiquiatria gaúcha reconhecida nacionalmente. $\mathrm{O}$ respeito às diferentes formas de pensamento e o acolhimento a diversas áreas da psiquiatria é marca registrada da Revista. Por isso todos temos um grande motivo para comemorar esses 30 anos de sucesso da nossa Revista.

Não há conflitos de interesse associados à publicação deste editorial.

Copyright (C) Revista de Psiquiatria do Rio Grande do Sul - APRS 